УАK 342.2

ББК 67.400 .5

DOI 10.22394/1682-2358-2017-6-131-136

S.R. Gadisov, senior lecturer of the Civil Law and Proceedings Department, Povolzhsky Institute of Management named after P.A. Stolypin, Branch of the Russian Presidential Academy of National Economy and Public Administration

\section{THE CATEGORY «GOVERNANCE» IN MODERN APPROACHES TO DETERMINING THE SOVEREIGNTY OF THE STATE}

The notion of «governance» in modern approaches to determining the sovereignty of the state is considered. The multidimensionality of «state sovereignty» and the concept of «state governance» are analyzed. The essence of state sovereignty is investigated.

Key words and word-combinations: state sovereignty, the state, state governance.
C.P. Гадисов, стариий преподаватель кафедри гражданского права и прочесса Поволжского института управления имени П.А. Стольпина - филиала Российской академии народного хозяйства и государственной служби при Президенте РФ (email: seymur01@bk.ru)

\section{КАТЕГОРИЯ «ВААСТЬ» B COBPEMEHHЫХ ПОАХОААХ К ОПРЕАЕАЕНИЮ СУВЕРЕНИТЕТА ГОСУААРСТВА}

\footnotetext{
Аннотация. Анализируются многоаспект-
} ность понятия «государственного суверенитета», уточняется определение понятия «государственная власть». Исследуется сущность государственного суверенитета.

Ключевые слова и словосочетания: государственный суверенитет, государство, государственная власть.

$\mathrm{O}_{\text {sp }}$ Аеления суверенитета в современной юриАической науке, нереАко можно встретить смешение понятий «суверенитет государства» и «суверенитет государственной вАасти». Из-за отсутствия в практике международных отношений и в политико-правовой теории общепризнанного подхода к преАставлению о суверенитете стацо возможным появление и существование целого ряла так называемых «полугосударств» (к их числу относятся и «непризнанные республики»). Находясь формально под вцастью и в составе конкретного государства, в реацьности они сформировали свою самостоятельную государственность. Такие факты указывают 
на актуальность принятия единого концептуального определения суверенитета, учитывающего состояние Аействующих правовых институтов, а также уровень развития современных политических систем. Вместе с тем до сих пор остается спорным вопрос: можно $\Lambda$ говорить о суверенитете как о характерном свойстве (признаке) государства или же это собственно и есть сама государственная вмасть?

Еще в начале XX в. отечественный правовед А.С. Ященко писал, что «воззрение, считающее суверенитет необходимым и сушественным признаком государства, принимается очень многими юристами, хотя надо сказать, и не пользуется особенным успехом среди русских ученых» [1, с. 199]. Это высказывание не потеряло своей актуальности и для современных ученых, занимающихся Аанной проблематикой.

В научной юридической среде используются подходы, согласно которым суверенитет считается кАючевым свойством или признаком государственности. К примеру, А.Б. Венгеров придерживается мнения, что суверенитет госуАарства стал важнейшей его чертой, заключающейся в независимости и вер-

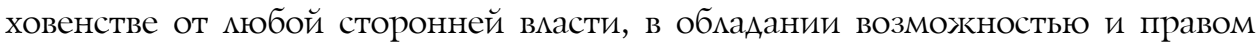
реализовывать от имени всего обшества внешнюю и внутреннюю политику [2, с. 92]. Н.А. Ушаков, исследуя институт государства, отмечац, что это специфическая организация, управцяющая демами проживающего на опредеменной территории человеческого общества и наделенная особым свойством суверенитета [3, с. 272].

Общепризнанным является представление, согласно которому понятие «суверенитет» напрямую ассоциируется с понятием государственной власти, мибо с ней отождествляясь, мибо рассматриваясь как ее непременное свойство. Во многих теориях государственный суверенитет определяется через конструкцию «верховенства государственной власти в пределах страны и независимости ее в межкународных отношениях» [4, с. 58]. Приведем некоторые примеры, объясняющие такой подход. Советский правовеА Я.М. Магазинер писал, что нет более высокой власти в пределах страны, чем государственная

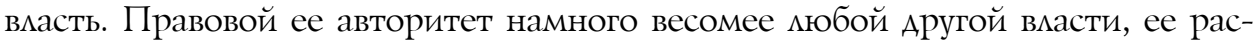
поряжения обладают наивысшей правовой силой, иными словами, это есть верховная власть, то есть выше нее нет в государстве, а высшая власть по-Аругому именуется суверенной [5, с. 228].

Необходимо отметить, что позиџия, при которой отождествцяются очевиАно неоднозначные, понятия государства и государственной власти, не является методологически верной. В связи с этим вопрос, правомерно $и$ опреАелять суверенитет государства через понятие «государственная вцасть», остается открытым.

Анализ термина «государственная власть» приводит к выводу о многоаспектности его содержания. Б.А. Кистяковский сделал акцент на том, что власть в прямом смысле заключается в субъективном праве. «Право властвования» в переносном значении используется, чтобы обозначить мицо или учреждение, которое осуществляет это право. Исследователь определяет госуАарство субъектом этого права [6, с. 379-380]. «ВАасть» раскрывается через 
призму категорий «политическое господство», «государственное управление и его органы», приобретая свойства государственной вмасти. При этом право и возможность распоряжения кем-либо или чем-либо, а также органы или мица, обладающие административными или правительственными полномочиями, несут в себе структурные и вцастные характеристики.

ОАнако функционацьные особенности государственной вмасти, как и ее структура, не могут совпадать с функциями государства и его структурой. Возможности государства не сводятся к возможностям государственной власти. Так, соглашения и договоры межАу государствами заключаются по сути межАу властями этих государств, при этом данные договоры явцяются межгосуАарственными. Во время революций, при свержении прежней власти Аоговоры, как правило, сохраняются, так как закцючались они именно отдельными государствами.

Приравнивание власти государства к властным полномочиям органов госуАарства восходит к укрепившимся в общественном сознании преАставлений о государстве как системе органов государственной власти. Государство существует в течение многих столетий, и на протяжении этого времени органы вмасти являются его еАинственным полноправным представителем. Государственная власть первична по отношению к государственным органам и не явцяется их суммой. Именно принадлежность к государству опреАеляет компетенџию, функции и полномочия органов государственной власти.

Еще одной существенной характеристикой рассматриваемого вопроса выступает то обстоятельство, что власть не может существовать сама по себе. Чтобы она существовала, требуется не менее Авух субъектов, из которых оАному принадлежит вмасть. В качестве вцастного может выступать один из органов государства или даже их вся совокупность, государство в целом как единая организация или корпорация. В данном случае государственная власть может быть определена как возможность и способность государства в решающем воздействии на общественные отношения.

Власть явмяется качественной характеристикой государства, но не тождественной ему. При этом даже при намичии народа, территории и вмасти государство можкет и не возникнуть. И. Изензее, размышияя над определением государства, писал о нем как о нечто большем, чем сумма трех элементов, составляющих только «скелет органического целого, живого, Аействующего единства» [7, с. 26]. В основе государства межит их взаимосвязь и единство, без чего эти эмементы не могут привести к образованию государства.

Независимость, суверенитет - главные признаки государства. При подобном понимании государства суверенитет выступает как характеристика составных частей, которые необходимы дия появцения государства, а не только государственной власти. Государственный суверенитет, в свою очереАь, преАставцяет собой совокупность суверенитетов народа, территории, вмасти.

Наиболее важное место в системе элементов государства принадлежит народу. Утвердицось мнение, в соответствии с которым суверенитет государства явцяется производным от суверенитета народа, что находит отражение в Конституции РФ (п. 1 ст. 3): «Носителем суверенитета и единственным источни- 
ком власти в Российской Федерации является ее многонациональный народ». С.В. Черниченко считает, что утверждение «носитель суверенитета - народ» выглядит заманчиво, тем не менее необходимо отметить, что «носителем суверенитета явмяется государство, а народ - его источником». Суверенитет представляется олиџетворением правовой самостоятельности, независимости и верховенства государства. Государство - это не народ, и входяшие в государственный аппарат мюди - это тоже не народ, несмотря на то что общество создает данный аппарат и не теряет опредеменной связи с ним (Аругими словами, формирует с этим аппаратом организацию, которую в более широком значении именуют государством). Как структуры властвования государства без граждан, конечно, не было бы. ОАнако Ааже сам термин «тосударственный суверенитет» подтверждает, что носителем его выступает государство. Таким образом, часто встречающийся в конституџиях тезис «НароА - носитель суверенитета» относится по большей части к политическим мозунгам [8, с. 26] .

Народ представмяет собой преАпосылку, источник государственной вмасти и одновременно важный государственный элемент. Если же народ рассматривать в качестве элемента государства, то вряд $\Lambda$ верно говорить о суверенитете. Народный суверенитет имеет проявления только во время голосования за основной закон государства и в период выборов высших органов государства, после этого суверенитет народа переходит к государству. В связи с этим можно утверждать, что суверенитет народа не является элементом государства.

Независимость и верховенство - это именно те характеристики суверенитета, которые определяют внутренний и внешний курс государства вне зависимости от остальных государств. Исходя из этого, можно сделать вывоА, что суверенитет государства делится на две составляющие: внешнюю (независимость) и внутреннюю (верховенство). В научной китературе взамен термина «внутренний суверенитет» нередко используют такое выражение, как «территориальное верховенство государства». Аанный термин обозначает «территориальный суверенитет» [9, с. 63], «осуществление государством, суверенной власти наА всеми организаџиями и миџами в пределах своей территории (imperium) и верховном публично-правовом владении этой территорией (dominium)» или «высшую власть по отношению ко всем киџам и организаџиям, находящимся в предемах его территории, искмючающей деятельность публичной власти Аругого госуАарства» [10, с. 285] .

Ряд исследователей рассматривает суверенитет территории в качестве самостоятельной правовой категории. С.Б. Торрес считает, что территориальный суверенитет - это «полная и исключительная власть над всей спорной территорией» [11, с. 823]. При этом следует обратить внимание, что, суверенитет, как и власть, не может сушествовать сам по себе. Необходим не только субъект, который имеет суверенитет, но и субъект, который противостоит ему и может как иметь суверенитет, так и не иметь его. Территория в связи с этим выступает как необходимая, но недостаточная предпосылка для формирования государства. Она может быть объектом или характеристикой, признаком ици эмементом субъекта, то есть самого государства.

Употребление в научных исследованиях категории «территориальный су- 
веренитет», который понимается как главенство государственной вмасти наА определенной территорией и независимость Аанной территории от власти Аругих государств, ничем не отличается от понимания государственного суверенитета в плане верховенства и независимости государственной власти. Подобное перефразирование некорректно, так как не привносит ничего нового в познание категории суверенитета, а мишь размывает его содержание. В то же время, государственная вмасть не может иметь суверенитет или представмяться как суверенная вцасть.

ОАнако, как показывает история, все гораздо сложнее. Например, Россия после краха монархии и перехода вмасти к большевикам в течение нескольких месяцев находилась в состоянии комлапса. Высшие органы государственной власти не действовали, указы Временного правительства, как правило, не выполнялись, поэтому требовалась сила, способная взять на себя управление страной, которой и стали большевики. Период с конџа августа по начало сентября 1917 г. стац временем, когда у Временного правительства фактически не бымо власти. Территория бывшей империи стала распадаться на части, объявцявшие о своем суверенитете (Украина, прибалтийские государства, Финмяндия). При этом, хотя и номинально, в России существовала центральная государственная власть. Существование государственной власти только в теории, так же как и нацичие мишь территории ици населения, еше не образует государства.

Государственная вцасть выступает как производная от государства и, по мнению М.Н. Марченко, она сама по себе не имеет суверенитета, а «наде-

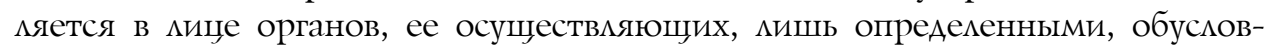
менными соотношением соџиально-политических сил в обществе и многими Аругими факторами, полномочиями». При этом суверенитет относится ко всему государству [12, с. 71]. Суверенитет и виасть выступают признаками государства. В результате объяснение сути государственного суверенитета через понятие «государственная вмасть» приводит к тому, что одной характеристикой субъекта определяется другая характеристика того же субъекта.

Опыт межАународно-правовой деятельности свидетельствует о том, что обмадателем государственного суверенитета, а значит и соответствующих суверенных обязанностей и прав, признается не государственная вцасть или какоймибо конкретный государственный орган, а мишь само государство. Внутри страны только государство может реацизовывать верховную (высшую) власть наА своим населением. Вовне же ему принадлежат такие права, как право на равноправное чценство в международных структурах; право на участие в «универсальных межАународных Аоговорах без какой-либо Аискриминации»; право на межАународное сотрудничество и общение с иными государствами; право на мир и Аругие [12, с. 192] .

Г. ЕАлинек в одном из своих многочисленных исследований писал о госуАарственном суверенитете как способности государства к «искиючитеиьному правовому самоопределению». Суверенное государство, по его мнению, «может - в пределах, установленных или признанных им самим правовых границ - совершенно свободно формировать содержкание своей компетенџии». 
Соответственно суверенная государственная власть не знает « ... над собой никакой высшей власти; поэтому она является в то же время независимой и верховной властью. Первый признак проявмяется преимущественно вовне, в сношениях суверенного государства с другими державами, второй - во внутренних отношениях, по сравнению с входящими в состав государства мицами» $[13$, с. 363]. Р.И. Захарьян считает что государственная власть - один из признаков государства, наравне с территорией и населением. Суверенитетом, то есть верховенством и независимостью, может обладать только государство $[14$, c. $15-18]$.

Суверенитет как неотъемлемое свойство ици признак государства имеет проявление и практическую реализаџию кишь через государственную власть. При этом государственный суверенитет олиџетворяет собой независимость и верховенство государства, явмяющегося субъектом политической и правовой жизни и проявляется как через государственную власть, так и через единство и взаимосвязь народа и территории, с характерными только для них признаками и свойствами.

Следовательно, понятие «суверенитет государства» можно раскрыть только через категории верховенства и независимости государства, а не верховенства и независимости государственной вмасти, так как, по нашему мнению, суверенитет государства - категория более объемная и вкмючает в себя госуАарственную власть (суверенную). Безусловно, мишь суверенное государство может обеспечить суверенитет государственной вмасти.

\section{Библиографический список}

1. Ящеенко А.С. Философия права Владимира Соловьева. Теория федерализма. Опыт синтетической теории права и государства. СПб., 1999.

2. Венгеров А.Б. Теория государства и права. М., 2005.

3. Ушаков Н.А. Суверенитет в современном международном праве. М., 1963.

4. Марченко М.Н. Государство и право в условиях глобализации. М., 2008.

5. Магазинер Я.М. Лекции по государственному праву. Пг., 1919.

6. Теория государства и права: хрестоматия: в 2 т. Т. 1: Государство / авт.-сост. М.Н. Марченко. М., 2004.

7. Изензее И. Государство / пер. с нем. // Вестник Моск. ун-та. Сер. 12: Социально-политические исследования. 1992.

8. Черниченко C.B. Государство как личность, субъект международного права и носитель суверенитета // Российский ежегодник международного права. СПб., 1995.

9. Молодцов C.B. Некоторые вопросы территории в международном праве // Советское государство и право. 1954. № 8.

10. Тимченко Л.Д. Международное право. Харьков, 1999.

11. Торрес Б.С. Территориальная суверенность // Энциклопедия международного права. 2000

12. Марченко М.Н. Теория государства и права: учебник. 2-е изд., перераб. и доп. М., 2006

13. Еллинек Г. Общее учение о государстве. СПб., 1908.

14. Захарьян Р.И. Понятия «суверенитет государства» и «суверенитет государственной власти» в их соотношении // Право и государство: теория и практика. 2010. № 1. 